\title{
Pertumbuhan Ekonomi, Distribusi Pendapatan dan Lingkungan ${ }^{1}$
}

\author{
M.Suparmoko
}

The goal of the economy development is to increase the welfare of a nation. The welfare is often indicated by the low or the high of the country's income per capita. However, recently the environmental factor should be included in the formulation of the income per capita of a country as a green national income. Firstly, this paper discusses the relationship between the income per capita and the income distribution. Secondly, the discussion includes the assessment of the income distribution imbalance focusing on the aspects of Imbalance Ratio, Lorenz Curve, and Gini index. Lastly, Kuznet Curve is crucial to be used in the economic development analysis as an environmental factor in the income per capita of a country.

Kata kunci: pembangunan ekonomi, distribusi pendapatan, pemerataan

$\mathrm{T}$ ujuan pembangunan ekonomi tidak lain adalah untuk meningkatkan kesejahteraan suatu bangsa. Seringkali kesejahteraan ini diukur dengan tinggi rendahnya pendapatan per kapita bangsa tersebut. Bila pendapatan per kapita tinggi dikatakan bahwa negara tersebut telah maju atau disebut negara berkembang; sedangkan bila pendapatannya rendah dikatakan bahwa negara tersebut masih terbelakang atau sedang berkembang. Alat ukur pendapatan per kapita ini telah mendapatkan kritikan yang tidak sedikit karena sebenarnya pendapatan per kapita itu hanya diperlukan untuk mengetahui atau mengukur maju tidaknya suatu perekonomian walaupun sebenarnya kurang tepat bila digunakan untuk mengukur tinggi rendahnya kesejahteraan suatu bangsa.
Untuk mengatasi kelemahan tersebut, telah diusulkan oleh banyak ahli ekonomi bahwa ukuran pendapatan per kapita itu harus dilengkapi dengan melihat bagaimana distribusi pendapatan di negara yang bersangkutan. Bila distribusi pendapatan bersifat merata, dan pendapatan per kapita itu tinggi maka ini mencerminkan adanya tingkat kesejahteraan yang merata; artinya pendapatan yang ada di negara tersebut dinikmati secara merata oleh banyak penduduk. Oleh karena itu adalah benar

1 Materi pokok makalah ini pernah disampaikan pada "Seminar dan Workshop Perencanaan Pembangunan Dengan Pendekatan Tannas," Program Pengkajian Ketahanan Nasional, Program Pascasarjana Universitas Indonesia, pada tanggal 1 November 1996, di Jakarta dan telah direvisi dengan menambahkan pendekatan terhadap lingkungan hidup. 
bahwa tujuan pembangunan ekonomi adalah peningkatan pendapatan per kapita rii] dan sekaligus disertai dengan distribusi pendapatan yang semakin merata.

Namun demikian perfu disasdari bahwa Akhir-akhir ini dengan mencuatnya isu lingkungan, ukuran pendapatan per kapita atas dasar penghitungan konvensional sudah tidak tepat lagi karena dasar penghitungan pendapatan tersebut belum memasukkan dimensi lingkungan sebagai salah satu faktor pertumbuhan ekonomi yang harus diperhitungkan. Apabila dimensi lingkungan sudah diperhitungkan dalam penghitungan pendapatan nasional, maka pendapatan itu disebut dengan pendapatan nasional hijau. ${ }^{2}$

\section{Hubungan Antara Pendapatan Per Kapita dan Distribusi Pendapatan}

Seperti telah disinggung di atas bahwa kesejahteraan hidup yang lebih tinggi bagi suatu bangsa dapat dicapai bila pendapatan per kapita méningkat disertai dengan distribusi pendapatan yang semakin merata pula. Tampaknya pembicaraan mengenai distribusi pendapatan agak terkesampingkan saat ini dan lebih banyak pembicaraan mengenai aspek lingkungan hidup.

Dalam membicarakan masalah distriBusi pendapatan biasanya dibedakan antara distribusi perorangan (size distribution) dan distribusi fungsional (functional distribution). Size distribution membahas mengenai distribusi pendapatan antar individu atau rumah tangga, sedangkan functional distribution membicarakan distribusi pendapatan antar faktor produksi seperti tenaga kerja, modal dan tanah. Di antara kedua pengukuran-itu, para ekonom lebih banyak menggunakan cara yang pertama untuk menunjukkan tingkat pemerataan atau keadilan dalam perekonomian suatu negara. Memang dalam pengukuran itu tidak pemah dipersoalkan proses bagaimana dan dari mana penerima pendapatan memperoleh pendapatan mereka; seperti apakah pendapatan itu berasal dari menjual tenaga kerja, memperoleh bunga modal, mendapatkan sewa lahan ataupun menerima bagian laba.

Pada umumnya dihipotesiskan bahwa pertumbuhan ekonomi.yang cepat akan dibarengi dengan distribusi pendapatan yang tidak merata, karena pertumbuhan ekonomi yang cepat menghendaki digunakannya teknologi yang bersifat padat modal dan bukan padat karya. Banyak pengalaman menunjukkan bahwa teknologi padat modal akan membawa dampak pada semakin tidak meratanya distribusi pendapatan. Lebih jauh lagi diargumentasikan bahwa untuk pertumbuhan ekonomi yang cepat justru distribusi pendapatan yang tidak merata itulah yang diperlukan, karena harus ada sekelompok pendudukyang penghasilannya tinggi dan mampu membentuk tabungan untuk disalurkan menjadi investasi yang diperiukan bagi pertumbuhan. ${ }^{3}$

Di pihak lain ada argumentasi bahwa keadaan sekarang ini berbeda dengan keadaan negara maju pada waktu mereka mulai dengan pembangunan ekonominya di mana kelompok kaya yang ada di negara sedang berkembang tidak melakukan tabungan, melainkan menggunakan pendapatannya yang tinggi itu untuk keperluan konsumsi mewah guna membeli

2 M.Suparmoko, "Neraca SDAL untuk Pembangunan Berkelanjutan" dalam M.Suparmoko Editor Neraca Sumberdaya Alam (Natural Resource Accounting), BPFE, Yogyakarta, 2005.

${ }^{3}$ Arthur Lewi's, The Theory of Economic Growth, George Alles \& Urwin Ltd., London, 1965 
barang-barang impor yang bermerek dan melakukan perjalanan ke luar negeri dan berbelanja di sana. ${ }^{4}$ Dengan kata lain investasi bagi pembangunan tidak banyak terjadi di negara sedang berkembang.

Selanjutnya kelompok miskin di negara sedang berkembang di samping pendapatannya rendah dan tingkat hidup serta kesehatannya rendah, juga pendidikannya rendah dan kekurangan gizi, dan akan berakibat lebih lanjut pada rendahnya produktivitas kerja mereka, sehingga menyebabkan pertumbuhan ekonomi menjadi semakin lamban. Oleh karena itu distribusi pendapatan yang tidak merata di negara sedang berkembang perlu dihapuskan. Teori tetesan ke bawah (trickle down effect) menyatakan bahwa dengan pembangunan ekonomi yang berhasil kelompok miskin akan secara otomatis mendapatkan bagian dari hasil pembangunan. Namun hal ini tidak dapat berlaku dalam waktu singkat. Orang miskin tidak tahan lagi menunggu sampai kapan akan terjadi tetesan ke bawah itu seandainya distribusi pendapatan yang tidak merata dan konsentrasi kekayaan pada beberapa gelintir orang ditoleransi. Oleh karena itu pendekatan pembangunan yang tepat menghendaki adanya pertumbuhan yang sekaligus disertai dengan pembagian pendapatan yang lebih merata.

Namun demikian dari penelitian yang diadakan oleh beberapa ekonom diantaranya Simon Kuznets ${ }^{5}$ ditemukan bahwa tidak ada hubungan antara pertumbuhan ekonomi dan distribusi pendapatan. Memang telah ditemukan bahwa untuknegara-negara yang tergolong sudah maju ketidakmerataan pendapatan ada pada derajat rendah dan moderat; sedangkan untuk negara yang sedang berkembang distribusi pendapatan tersebar, yaitu ada yang rendah, moderat maupun tinggi. ${ }^{6}$ Dengan kata lain untuk negara sedang berkembang pola distribusi pendapatan tidak jelas hubungannya dengan tingkat pendapatan per kapitanya, tetapi sangat pasti bahwa untuk negaranegara yang telah maju distribusi pendapatan selalu dalam keadaan yang lebih merata (low inequality). Perhatikan Tabel 1.

Salah satu alasan yang dapat dikemukakan mengapa negara maju memiliki distribusi pendapatan yang lebih merata adalah karena di negára maju terdapat sistem kesejahteraan sosial (social security system) yang memadai dan sistem pajak umumnya bersifat progresif. Sistem kesejahteraan sosial ini sangat lemah di negara sedang berkembang termasuk Indonesia. Pemerintah Indonesia sejauh ini tidak mengembangkan sistem kesejahteraan sosial yang baik, sehingga setiap individu/rumah tangga berusaha sekuat tenaga untuk mengembangkan sistem. pengurangan resiko bagi anggota keluarganya di masa datang dengan mengoptimalkan tingkat pendapatan yang

${ }^{4}$ Kasus ini disebut sebagai "demonstration effect", lihat Irawan dan Suparmoko, Ekonomika Pembangunan, BPFE ,Yogyakarta, Edisi 6, 1990

${ }^{5}$ Hollis Chenery, Montek S Ahluwalia, C.L.G Bell, John H. Duloy, Richard Jolly, Redistribution with Growth, Oxford University Press, Singapore, 1975

${ }^{6}$ Distribusi pendapatan dikatakan sangat tidak merata (high inequality) bila $40 \%$ penduduk termiskin hanya mendapat kurang dari ' $12 \%$ pendapatan nasional, moderat (moderat inequality) bila mendapatkan antara $12-17 \%$ bagian pendapatan nasional, dan rendah (low inequality) bila mendapatkan bagian pendapatan nasional di atas $17 \%$. Lihat E.Wayne Nafziger, The Economic of Developing Countries, Prentice Hall, New Jersey, 1990, hal 105. 
Pertumbuhan Ekonomi, Distribusi Pendapatan dan Lingkungan; M.Suparmoko

Tabel 1.

Pengelompokkan Negara Menurut Tingkat Pendapatan dan Ketimpangan Distribusi, 1973

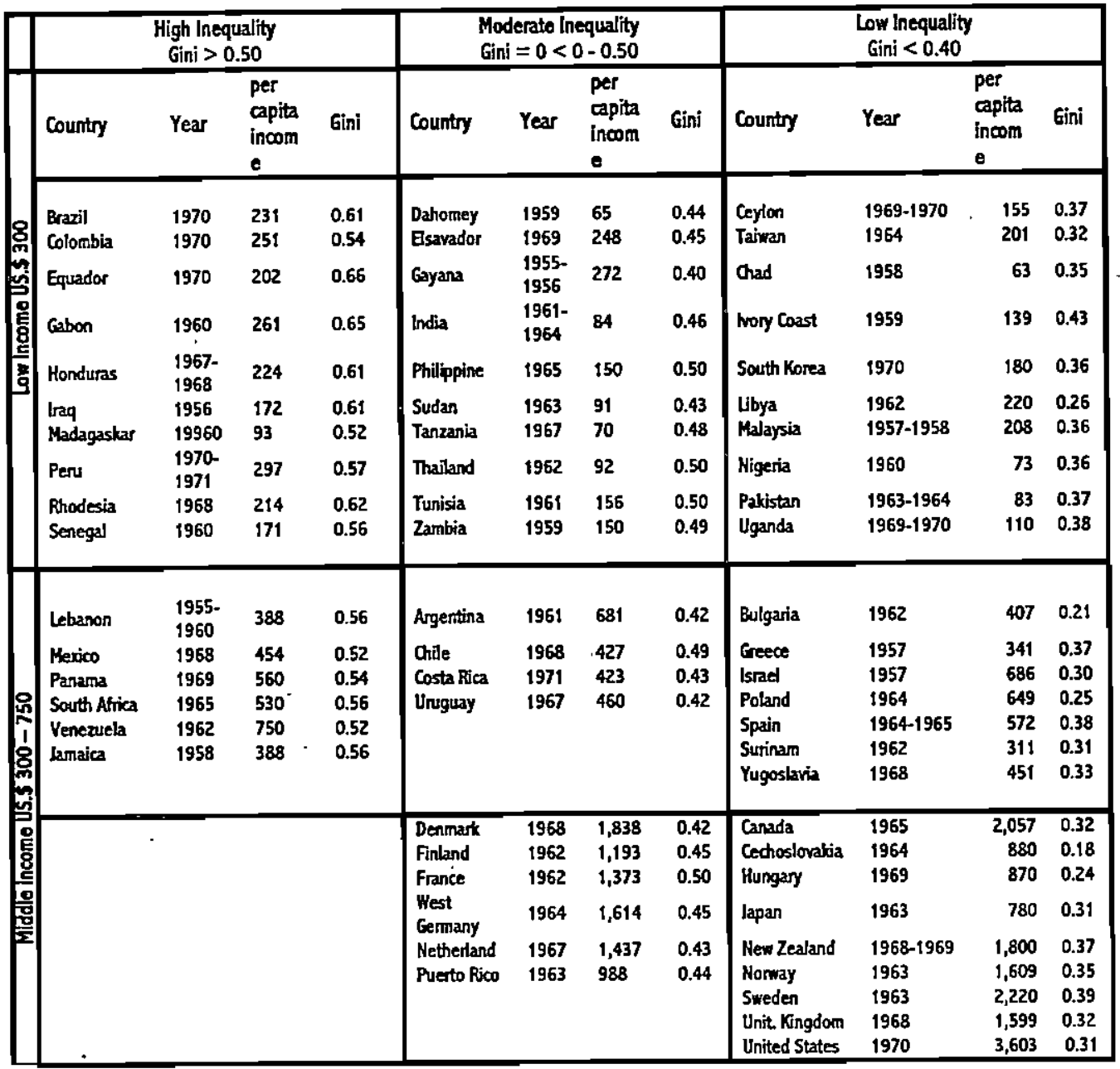

Source: Montek Ahluwalia, "Some Dimension of the Problem" in H.Chenery, C.L.G. Bell, John H, Duloy and R.Jolly, Redistribution with Growth: An Approach to Policy, Washington, D.C.: (IBRD. 1973) (mimeo), Reprinted by permission of The World Bank and Oxford University Press.

bisa dicapai walaupun akhirnya dengan menghalalkan segala cara. Tidak ada jaminan sekolah bebas biaya dari pemerintah. Juga tidak ada bantuan yang cukup untuk mereka yang kekurangan dan membutuhkan seperti "low cost housing", "free lunch program untuk anak sekolah, dan sebagainya.

Di negara sedang berkembang tingginya ketidakmerataan distribusi $\cdot$. 
Topik: Manajemen Negara dan Nasionalisme

Tabel 2

Distribusi Pendapatan Individual dalam Quintiles dan Deciles

\begin{tabular}{|c|c|c|c|}
\hline \multirow[t]{2}{*}{ Individual } & \multirow{2}{*}{$\begin{array}{l}\text { Personal Income } \\
\text { (money units) }\end{array}$} & \multicolumn{2}{|c|}{$\begin{array}{c}\text { Percentage share in } \\
\text { total income }\end{array}$} \\
\hline & & Quintiles & Deciles \\
\hline 1 & 0,8 & & \\
\hline 2 & 1,0 & & \\
\hline 3 & 1,4 & & \\
\hline 4 & 1,8 & 5 & 3.2 \\
\hline 5 & 1,9 & & \\
\hline 6 & 2,0 & & 3.9 \\
\hline 7 & 2,4 & & \\
\hline 8 & 2,7 & 9 & 5.1 \\
\hline 9 & 2,8 & & \\
\hline 10 & 3,0 & & 5.8 \\
\hline 11 & 3,4 & & \\
\hline 12 & 3,8 & 13 & 7.2 \\
\hline 13 & $\overline{4,2}$ & & \\
\hline 14 & 4,8 & & 9.0 \\
\hline 15 & 5,9 & & \\
\hline 16 & 7,1 & 22 & 13.0 \\
\hline 17 & 10,5 & & \\
\hline 18 & 12,0 & & 22.5 \\
\hline 19 & 13,5 & & \\
\hline 20 & 15,0 & 51 & 28.5 \\
\hline Total 100 & 100,0 & 100 & $10 \overline{0}$ \\
\hline
\end{tabular}

Measure of inequality - Ratio of bottom $40 \%$ to top $20 \%=14 / 51(0,28)$

Sumber: Michael Todaro, op.cit.

pendapatan disebabkan oleh beberapa faktor ${ }^{7}$ :

1. Pemilikan tanah dan penguasaan tanah sangat tidak merata.

2. Masih kurangnya tenaga ahli dan tenaga profesional, sehingga tingkat pendapatan mereka menjadi sangat tinggi relatif terhadap pendapatan sebagian besar penduduk pada umumnya.

3. Adanya ketidak sempurnaan pasar dan kurangnya mobilitas tenaga kerja, sehingga untuk kelompok tertentu penghasilannya tetap tinggi, dan yang lain tidak meningkat.

4. Sistem Pajak dan subsidi masih kurang efektif dalam mendistribusikan pendapatan.

5. Kebijakan harga, pajak, subsidi, kredit dan sebagainya masih cenderung memihak kelompok kaya.

7 Jan S. Hogendom, Economic Development, Harsper Coilins Publisher, 1992, Second Edition, hal 44. 


\section{Mengukur Ketimpangan Distribusi Pendapatan}

\section{Rasio ketimpangan}

Ketimpangan distribusi pendapatan yang ada dalam setiap perekonomian itu perlu digambarkan secara jelas. Untuk itu diperlukan suatu visualisasi atau suatu angka atau suatu ukuran sebagai indeks distribusi pendapatan. Cara paling umum dan sederhana adalah dengan mengurutkan para individu sesuai dengan urutan pendapatannya mulai dari yang terendah sampai ke yang tertinggi dan dinyatakan dalam persentase (share). Kemudian individu tersebut dikelompokkan menjadi lima kelompok (quintiles) atau ke dalam sepuluh kelompok (deciles), lalu ditentukan berapa bagian pendapatan yang diterima oleh setiap kelompok individu tersebut. Untuk menentukan apakah terdapat distribusi yang merata atau tidak, dilihat $40 \%$ dari seluruh individu yang ada mendapat bagian berapa persen dari total pendapatan. Hal ini sama dengan melihat persentase kumulatif pendapatan yang bersangkutan. Dari contoh pada Tabel 2 dapat diketahui bahwa $40 \%$ individu dengan pendapatan terendah memperoleh bagian $14 \%$ pendapatan; dan $20 \%$ individu dengan pendapatan tertinggi memperoleh bagian $51 \%$ pendapatan. Derajat ketimpangan dapat diukur dengan membandingkan dua nilai tersebut untuk memperoleh suatu angka (rasio) ketimpangan setinggi 14/51 atau $0,28 .^{\circ}$ Ini berarti bahwa perekonomian memiliki ketimpangan rendah dalam distribusi pendapatan.

\section{Kurva Lorenz}

Kurva Lorenz merupakan alat yang banyak digunakan dalam membahas ketimpangan pendapatan. Kurva ini digambarkan dalam suatu kotak di mana sumbu horisontal menunjukkan persentase penerima pendapatan dan sumbu vertikal menunjukkan persentase pendapatan yang diterima (Gambar 1). Pada sumbu horisontal angka $20 \%$ menunjukkan $20 \%$ penduduk penerima pendapatan terendah, dan angka $70 \%$ menunjukkan $70 \%$ penduduk penerima pendapatan tertinggi. Sumbu vertikal menunjukkan persentase pendapatan yang diterima masing-masing kelompok penduduk (individu) dan angkanya bersifat kumulatif pula. Dengan demikian garis diagonal yang menghubungkan titik $O$ dengan O-' menunjukkan adanya distribusi pendapatan yang merata, artinya $20 \%$ dari jumlah penduduk memperoleh bagian $20 \%$ jumlah pendapatan, atau $70 \%$ jumlah penduduk memperoleh $70 \%$ jumlah pendapatan. Kurva Lorenz sendiri berbentuk cekung terhadap diagonal $00^{-}$. Ini menunjukkan bahwa semakin cekung kurva itu dan menjauhi garis diagonal OO-' berarti semakin timpang distribusi pendapatan. Hanya saja suatu kerancuan dapat timbul apabila ada dua kurva Lorenz yang berpotongan untuk suatu negara pada waktu yang berbeda, atau membandingkan derajat ketimpangan distribusi pendapatan antara dua propinsi pada waktu yang sama misalnya. (Lihat inset pada Gambar 1)

\section{Indeks Gini}

Langkah selanjutnya dalam mengukur ketimpangan distribusi pendapatan adalah dengan menggunakan indeks Gini. Indeks ini diperoleh dengan membagi seluruh luas daerah antara kurva Lorenz dan garis diagonal $O O^{\prime}$ pada Gambar 1 dengan seluruh luas

' Lihat Michael P. Todaro,_Economic Development in the Third World, Longman House, 1986, halaman $143-154$. 
Topik: Manajemen Negara dan Nasionalisme

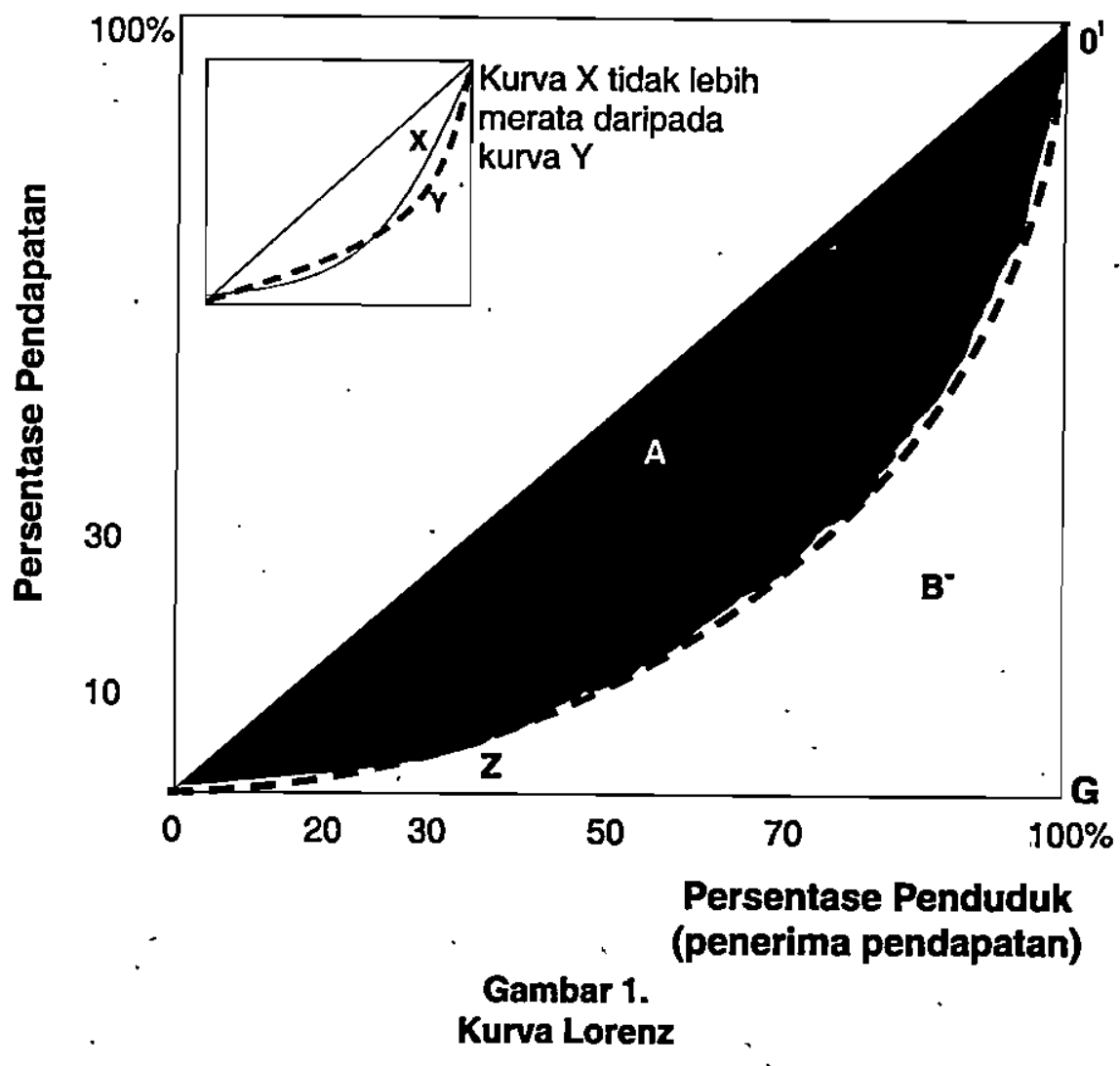

areal segitiga dibawah garis diagonal (segitiga OO'1G). Indeks Gini ini menunjukkan nilai pecahan. Semakin besar nilai indeks itu semakin tidak merata distribusi pendapatan di negara atau daerah yang bersangkutan. Dengan kata lain semakin jauh kurva Lorenz itu dari garis diagonal, semakin timpang distribusi pendapatan di negara yang bersangkutan dan semakin besar indeks Gini. Sebagai gambaran mengenai ketimpangan di berbagai negara perhatikan Tabel 3. Dari Tabel 3 tersebut tampak bahwa Indonesia pada tahun 1994 berada pada kondisi kesenjangan pendapatan yang relatif rendah dibanding dengan negara-negara lain yaitu dengan indeks Gini 31,7, sedangkan Brasil memilikj indeks Gini 73,4 yang berarti distribusi pendapatannya tidak merata. Apakah kondisi ini tetap atau berubah belum ada hasil penelitian yang dapat diacu. Walaupun demikian dapat dinyatakan 1997 dan sesudahnya, jumlah penduduk miskin di Indonesia telah meningkat jumlahnya.

Tabel 4 menunjukkan pula bahwa negara-negara sedang berkembang pada tahun 1994 masih selalu menghadapi distribusi pendapatan yang kurang merata dengan indeks Gini diatas 40 .

\section{Kurva Kuznets: Distribusi Pendapatan}

Kurva Kuznets menunjukkan hubungan antara kelompok pendapatan per kapita terendah $60 \%$ dengan kelompok pendapatan 
Pertumbuhan Ekonomi, Distribusi Pendapatan dan Lingkungan; M.Suparmoko

Tabel 3

GNP dan Indeks Gini Pembagian Pendapatan/Konsumsi di Delapan Negara Berkembang, 1995

\begin{tabular}{|l|l|c|c|c|c|}
\hline No. & Negara & $\begin{array}{c}\text { Jumlah } \\
\text { Penduduk } \\
\text { (juta) }\end{array}$ & $\begin{array}{c}\text { GNP } \\
\text { Per kapita } \\
1994 \text { (US\$) }\end{array}$ & $\begin{array}{c}\text { PPP dan GNP } \\
\text { Per kapita } \\
1994 \text { (US\$) }\end{array}$ & Indeks Gini \\
\hline 1 & Banglades & 117,9 & 220 & 1.330 & 28,3 \\
\hline 2 & Pakistan & 126,3 & 430 & 2.130 & 31,2 \\
\hline 3 & Indonesia & 190,4 & 880 & 3.600 & 31,7 \\
\hline 4 & India & 913,9 & 320 & 1.280 & 33,8 \\
\hline 5 & Nigeria & 108,0 & 280 & 1.190 & 37,5 \\
\hline 6 & Cina & $1.190,0$ & 530 & 2.510 & 37,6 \\
\hline 7 & Federasi Rusia & 148,3 & 2650 & 4.610 & 49,6 \\
\hline 8 & Brasil & 159,1 & 22.970 & 5.400 & 73,4 \\
\hline
\end{tabular}

Catatan: Kecuali Brasil yang termasuk negara berkembang berpendapatan menengah ke atas, tujuh negara lainnya adalah negara berkembang berpendapatan menengah ke bawah.

Sumber : World Development Report 1996.

\section{Tabel 4}

Indeks Gini, GNP dan PPP pada 57 Negara Berkembang, 1994

\begin{tabular}{|c|c|c|c|}
\hline $\begin{array}{l}\text { Kelompok } \\
\text { Negara }\end{array}$ & $\begin{array}{c}\text { GNP 1994 } \\
\text { (US\$) }\end{array}$ & $\begin{array}{c}\text { PPP dari GNP 1994 } \\
\text { (US\$)) }\end{array}$ & Indeks Gini \\
\hline I & $3 \overline{87}$ & 1.558 & 41.3 \\
\hline II & 1.726 & 4.194 & 40.0 \\
\hline III & 3.909 & 7.014 & 44.9 \\
\hline Rata-rata & 2.007 & 4.255 & 42.1 \\
\hline
\end{tabular}

Catatan: I. Negara berkembang berpendapatan rendah,

II. Negara berkembang berpendapatan menengah ke bawah,

III. Negara berkembang berpendapatan menengah ke atas.

Sumber : World Development Report 1996.

perkapita tertinggi $40 \%$. Kurva Kuznets ini menunjukkan distribusi pendapatan yang tidak berubah dengan meningkatnya pendapatan. (Lihat Gambar 2). Pada titik A misalnya $40 \%$ penduduk pada kelompok teratas menerima kira-kira $\$ 800$, dan $60 \%$ penduduk pada kelompok teréndah menerima kurang lebih $200 \$$. Pegeseran . kedudukan ke titikB dari titikA meningkatkan pendapatan masing-masing kelompok dan tidakmengubah distribusi pendapatan. Tetapi apabila terjadi perubahan dalam distribusi pendapatan menjadi semakin tidak merata, maka kurva Kuznets memotong sumbu horisontal. Sebaliknya bila distribusi pendapatan menjadi semakin merata kurva kuznets menjadi semakin landai dan memotong sumbu vertikal. 
Topik: Manajemen Negara dan Nasionalisme

Kaitan antara distribusi.pendapatan dan pertumbuhan ekonomi telah ditemukan oleh Simon Kuznets pada tahun 1954 bahwa ada hubungan yang berbentuk huruf $\mathrm{U}$ terbalik. Artinya dengan berkembangnya waktu, yang biasanya disertai dengan peningkatan pendapatan per kapita, koefisien atau indeks Gini mula-mula rendah, kemudian naik, lalu turun kembali seperti tampak pada Gambar 3. Namun demikian bentuk huruf U terbalik itu tidak tajam tetapi sedikit landai dan berubah secara gradual.

Jadi ada hubungan berbentuk huruf $U$ antara distribusi pendapatan dan tingkat pendapatan per kapita atau dinyatakan dalam hubungan pendapatan per kapita dengan koefisien Gini kurva itu berbentuk $U$ terbalik

\section{4) Kurva Kuznets: Lingkungan}

Indonesia dan Brasil merupakan negaranegara yang kaya akan hutan tropis dan hasil tambang pada tahun 1990an dan tampak pula pendapatan per kapita juga relatif tinggi bila dibanding negara-negara lain. Namun bila unsur deplisi sumberdaya alam juga diperhitungkan dan dikurangkan dari jumlah pendapatan perkapita yang ada, maka akan tampak bahwa pendapatan per kapita di kedua negara tersebut akan lebih kecil daripada yang di tampilkan dalam tabel

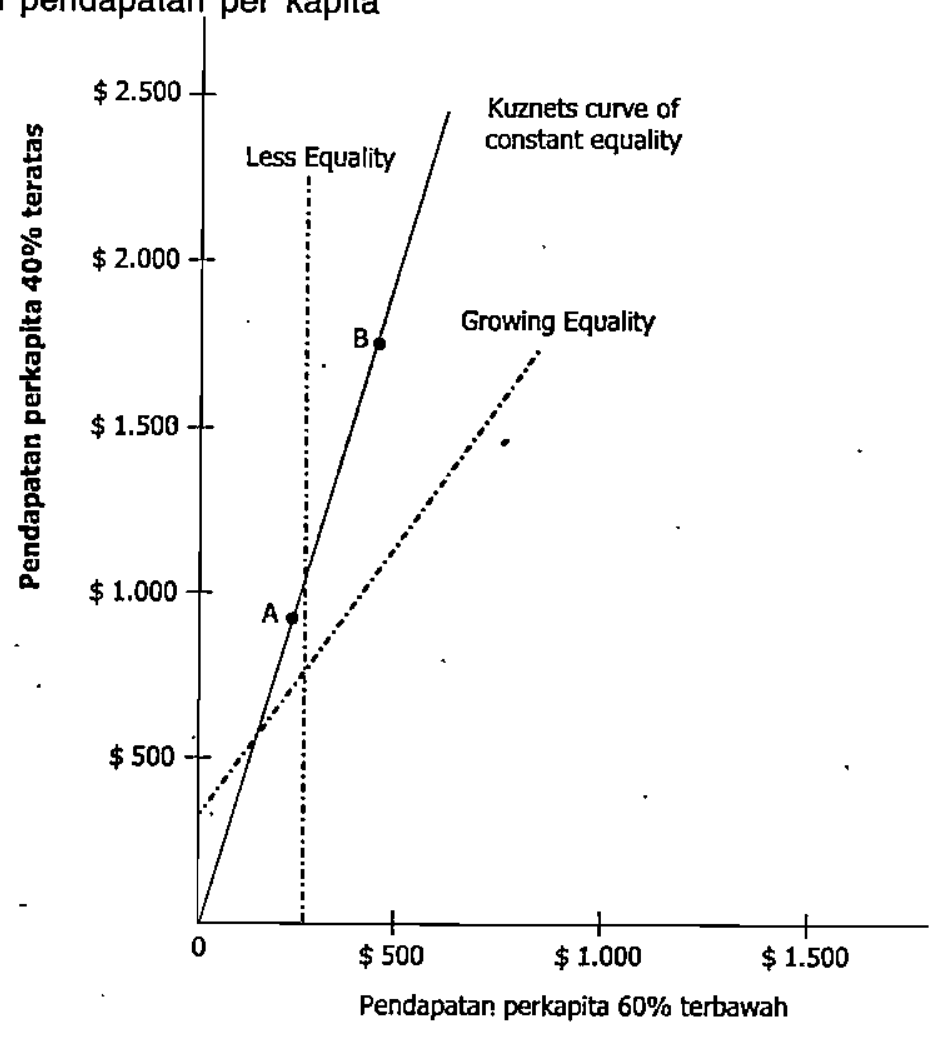

Gambar 2.

Kurva Kuznets

Sumber: Jan S. Hagendorn, Economic Development, ibid. 
Pertumbuhan Ekonomi, Distribusi Pendapatan dan Lingkungan; M.Suparmoko
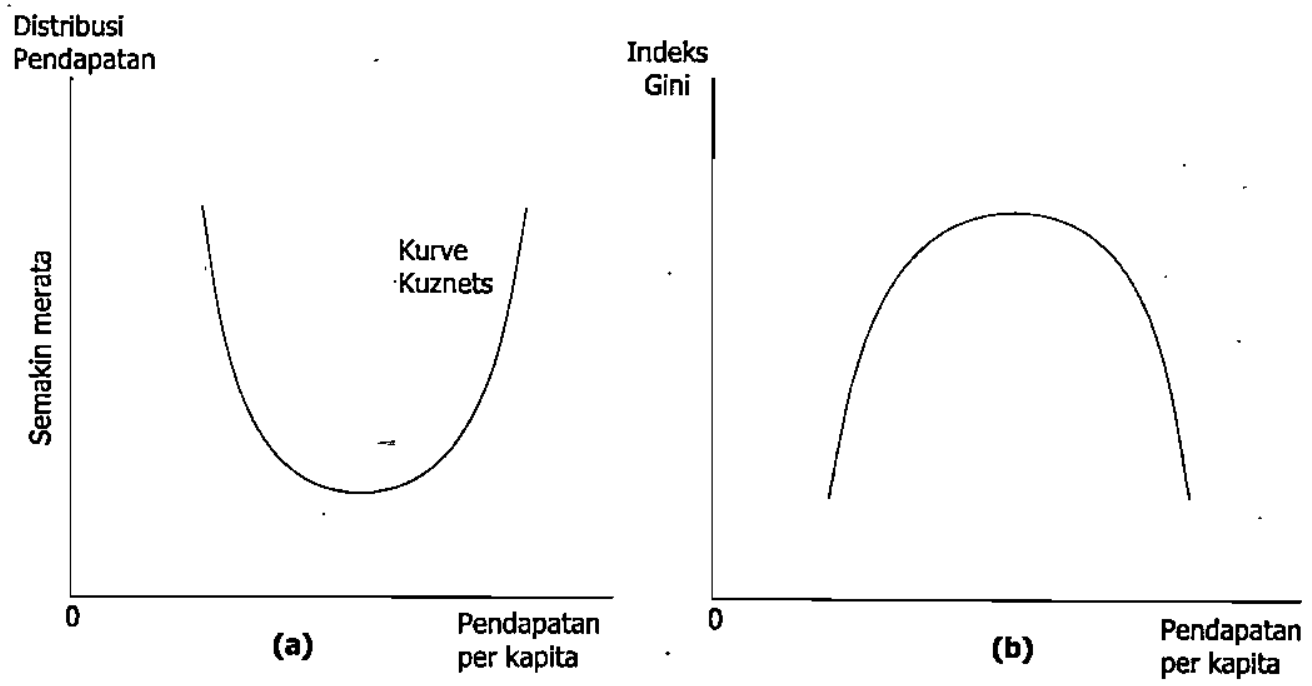

Gambar 3

Distribusi Pendapatan dan indeks Gini

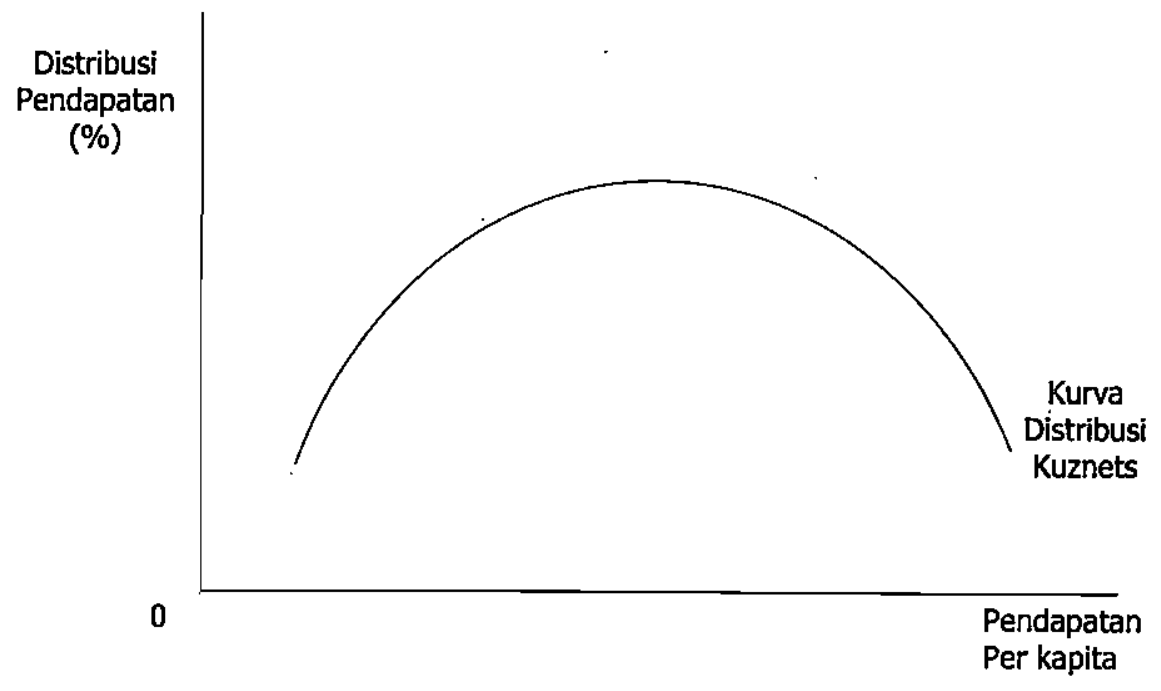

Gambar 4.

Bentuk huruf U terbalik Indeks Gini

tersebut. Repeto mencatat bahwa laju pertumbuhan ekonomi yang konvensional dinyatakan setinggi ( $7 \%$ per tahun) pada tahun 1971 - 1984 menjadi lebih rendah (4 $\%$ per tahun) setelah deplisi lahan, hutan dan minyak bumi diperhitungkan. ${ }^{9}$
${ }^{9}$ Reppeto, R., Wasting Asset: Natural Resources in The National Income dalam Markandya/Richardson, editors Environmental Economics, Earthscan, London, 1993, hal 364 $-388$ 
Topik: Manajemen Negara dan Nasionalisme

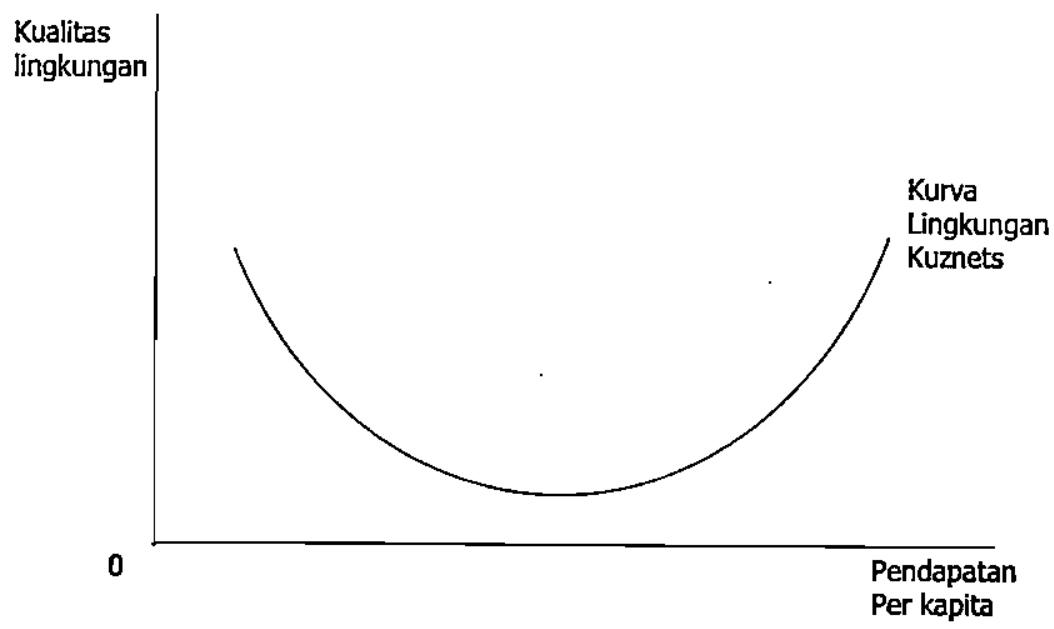

Gambar 5.a

Kurva Kuznets: Kualitas Lingkungan

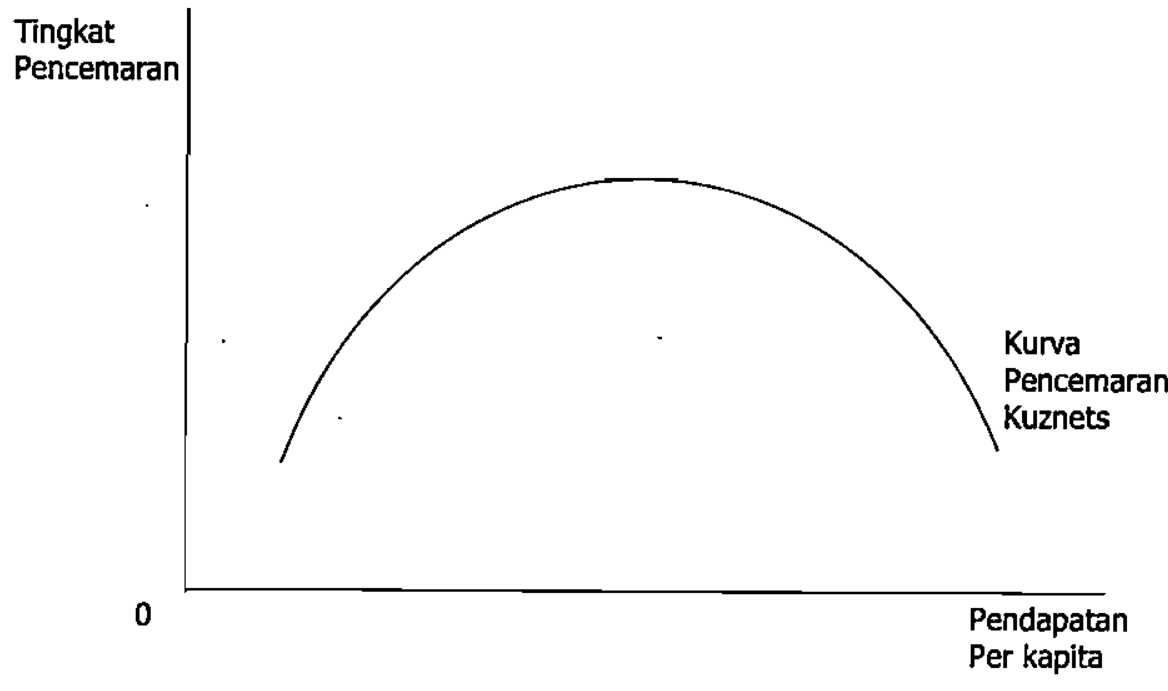

Gambar 5.b

Kurva Kuznets: Pencemaran Lingkungan

Kuznets juga menghubungkan pendapatan perkapita dengan kualitas lingkungan, di mana tingkat pendapatan perkapita yang sangat rendah dan yang sangat tinggi kondisi kualitas lingkungan baik adanya sedangkan pada tingkat pendapatan perkapita sedang, kualitas lingkungan sangat rendah.

Beberapa alasan mengapa gerakan dari indeks Gini itu mengikuti pola bentuk huruf 

berikut :

U terbalik dapat dikemukakan sebagai

1. Pada awal pertumbuhan ekonomi di negara-negara miskin, kelompok tertentu seperti para wiraswasta, tenaga ahli, tenaga terdidik, terutama di wilayah di mana pembangunan terjadi, akan mengalami kenaikan pendapatan secara cepat, sementara kelompok lain masih ketinggalan.

2. Terdapat perubahan struktur produksi yang berupa perpindahan penduduk dan tenaga kerja dari sektor pertanian (desa) ke sektor industri kota.

3. Menyertai pertumbuhan pendapatan adalah pertumbuhan penduduk di negara-negara yang relatif miskin; yang berakibat pada meningkatnya jumlah penduduk usia muda. Pada gilirannya akan menyebabkan ketimpangan distribusi pendapatan meningkat lagi.

4. Pemerataan akan terjadi kembali pada tahap berikutnya apabila dengan meningkatnya pendapatan, pendidikan meningkat bagi sebagian besar penduduk miskin dan laju pertumbuhan jumlah penduduk menurun.

\section{Penutup}

Sebagai penutup dari makalah ini dapat disimpulkan bahwa pembangunan ekonomi yang membawa kenaikan produksi barang dan jasa serta menguras sumberdaya alam dan jika tidak mengurangi fungsi lingkungan jelas akan meningkatkan taraf hidup atau kesejahteraan suatu bangsa. Namun yang dipersoalkan adalah apakah peningkatan kesejahteraan itu dirasakan oleh seluruh lapisan masyarakat? Dari sinilah timbul persoalan mengenai distribusi hasil pembangunan itu. Siapa yang menikmati hasil pembangunan yang paling banyak, dan siapa yang menikmati paling sedikit?
Siapa yang menanggung beban pencemaran lingkungan yang paling banyak? Dengan kata Jain apakah hasil pembangunan itu telah dinikmati secara adil?

Dalam kaitan ini timbul pemikiran apakah sebaiknya membesarkan kue terlebih dahulu dan membagi rata kemudian? Atau membesarkan kue sekaligus membagi rata kue tersebut? Dari segi etika tampaknya alternatif yang kedua yang dipilih; sehingga mau tidak mau harus ada usaha-usaha pemerataan penghasilan sementara usaha pembangunan terus dijalankan. Bahkan ada pemikiran dari pemerataan pembangunan dan kesejahteraan antar daerah melaluj "transier biaya" (cost transfer). Suatu daerah (A) yang memelihara lingkungannya dengan baik dan tidak menebang hutan, seharusnya dapat diberikan pembayaran jasa lingkungan dari daerah lain (B) yang mendapatkan manfaat hasil dari pemeliharaan hutan atau lingkungan di daerah A. Dengan demikian daerah atau kabupaten yang bersedia memelihara hutan sebagai hutan lindung akan tetap bisa membangun dengan dana transfer dari daerah lain yang mendapatkan manfaat karena terpeliharanya hutan di daerah yang satu tadi.

Selanjutnya metode untuk melihat mengenai ketimpangan distribusi pendapatan ada beberapa macam, diantaranya dengan menggunakan Kurva Lorenz, Indeks Gini, dan Kurva Kuznets serta kurva lingkungan Kuznets. Hendaknya analisis pembangunan mulai mengadaptasi informasi yang ditampilkan oleh Kurva Distribusi Kuznets sekaligus Kurva Lingkungan Kuznets. 
Topik: Manajemen Negara dan Nasionalisme

\section{Daftar Pustaka}

Chenery $H_{\text {., }}$ Ahluwalia, Montek S., Bell C.L.G., Duloy John H., Jolly Richard, 1975, Redistribution with Growth, Singapore:Oxford University Press.

Hogendorn Jan S.,1992, Economic Development, Second Edition, New York: Harsper Collins Publisher.

Irawan, Suparmoko.M,1990, Ekonomika Pembangunan, Edisi 6 Yogyakarta: BPFE.

Lewi's, Arthur, 1965, The Theory of Economic Growth, London: George Alles \& Urwin Ltd.

Reppeto, R.,1993, Wasting Asset: Natural Resources in The National Income dalam Markandya/Richardson, editors Environmental Economics, London:Earthscan.

Suparmoko.M, 2005, "Neraca SDAL untuk Pembangunan Berkelanjutan" dalam M.Suparmoko Editor Neraca Sumberdaya Alam (Natural Resource Accounting), Yogyakarta:BPFE, 2005.

Todaro Michael P.,1986, Economic Development in the Third World,NY: Longman House.

Nafziger E.Wayne,1990, The Economic of Developing Countries, New Jersey: Prentice Hall. 